\title{
Analisa Trafik Pengunjung Website dalam Pengembangan UI dan UX
}

\author{
${ }^{1}$ Ridwan Raafi'udin, ${ }^{2}$ Bayu Hananto, ${ }^{3}$ Catur Nugrahaeni PD \\ 1,2,3Fakultas Ilmu Komputer \\ 1,2,3 Universitas Pembangunan Nasional Veteran Jakarta \\ ${ }^{1}$ raafiudin@upnvj.ac.id, ${ }^{2}$ bayuhananto@upnvj.ac.id, ${ }^{3}$ catur.nugrahaeni@upnvj.ac.id \\ J1. Rs. Fatmawati, Pondok Labu, Jakarta Selatan, DKI Jakarta, 12450, Indonesia
}

\begin{abstract}
Abstrak - Perkembangan teknologi informasi dan komunikasi menggiring para pengguna untuk selalu memutakhirkan penerapan teknologinya. Hampir di setiap lapisan masyarakat baik di kalangan industri dalam persaingan bisnisnya maupun di bidang pendidikan untuk meningkatkan layanan pendidikan yang semakin baik. Website portal menjadi salah satu kewajiban yang harus dimiliki oleh universitas dalam rangka penyediaan layanan informasi kepada khalayak umum, yang memerlukan informasi. Dalam rangka peningkatan pelayanan informasi kepada khayalak tersebut diperlukan peningkatan dari berbagai aspek, seperti kecepatan akses, user interface, dan user experience. Pada penelitian ini, peneliti akan mencoba meningkatkan user experience pada website portal yang dimiliki Universitas Pembangunan Nasional Veteran Jakarta. Dengan peningkatan tersebut diharapkan akan meningkatkan kepuasan khayalak terhadap pemenuhan kebutuhan informasi yang bersumber dari kampus UPN Veteran Jakarta.
\end{abstract}

Kata kunci: Trafik Website, User Interface, User Experience

\section{Pendahuluan}

Perkembangan teknologi informasi dan komunikasi menggiring para pengguna untuk selalu memutakhirkan penerapan teknologinya. Hampir di setiap lapisan masyarakat baik di kalangan industri dalam persaingan bisnisnya maupun di bidang pendidikan untuk meningkatkan layanan pendidikan yang semakin baik.

Website portal menjadi salah satu kewajiban yang harus dimiliki oleh universitas dalam rangka penyediaan layanan informasi kepada khalayak umum, yang memerlukan informasi. Dalam rangka peningkatan pelayanan informasi kepada khayalak tersebut diperlukan peningkatan dari berbagai aspek, seperti kecepatan akses, user interface, dan user experience.

UX (User Experience) menilai seberapa kepuasan dan kenyamanan seseorang terhadap sebuah produk, sistem, dan jasa. Sebuah prinsip dalam membangun UX adalah khalayak mempunyai kekuasaan dalam menentukan tingkat kepuasan sendiri (costumer rule). Seberapa pun bagusnya fitur sebuah produk, sistem, atau jasa, tanpa khalayak yang dituju dapat merasakan kepuasan, kaidah, dan kenyamanan dalam berinteraksi maka tingkat UX menjadi rendah (Wiryawan, 2011).

Pada penelitian ini, peneliti akan mencoba memberikan masukkan dalam peningkatan user experience pada website portal yang dimiliki Universitas Pembangunan Nasional Veteran Jakarta. Dengan peningkatan tersebut diharapkan akan meningkatkan kepuasan khayalak terhadap pemenuhan kebutuhan informasi yang bersumber dari kampus UPN Veteran Jakarta. Di lain pihak pengembangan UX berkaitan dengan salah satu komponen penilaian yang dimasukkan dalam borang penelitian oleh Kemenristekdikti.

Dengan menggunakan instrument yang dapat mencacat dan menganalisa data trafik pengunjung website maka data tersebut dapat dijadikan sebagai landasan analisa untuk memberikan masukkan terhadap pengembangan user interface dan user experience . 


\section{Tinjauan Pustaka}

\subsection{Web Analytics (Analisis Web)}

Analisis Web adalah proses menganalisis perilaku pengunjung ke situs Web. Penggunaan analisis Web dikatakan memungkinkan bisnis untuk menarik lebih banyak pengunjung, mempertahankan atau menarik pelanggan baru untuk barang atau jasa, atau untuk meningkatkan volume dolar yang dihabiskan setiap pelanggan.

Analisis Web sering digunakan sebagai bagian dari analisis manajemen hubungan pelanggan (CRM analytics). Analisis ini dapat mencakup menentukan kemungkinan bahwa pelanggan tertentu akan membeli kembali suatu produk setelah membelinya di masa lalu, mempersonalisasikan situs tersebut kepada pelanggan yang mengunjunginya berulang kali, memantau volume dolar pembelian yang dilakukan oleh pelanggan individu atau oleh kelompok pelanggan tertentu, mengamati wilayah geografis dari mana pelanggan paling dan paling sedikit mengunjungi situs dan membeli produk tertentu, dan memprediksi produk mana yang paling dan paling tidak mungkin dibeli oleh pelanggan di masa depan. Tujuannya adalah untuk mempromosikan produk spesifik kepada pelanggan yang paling mungkin membelinya, dan untuk menentukan produk mana yang paling mungkin dibeli oleh pelanggan tertentu. Ini dapat membantu meningkatkan rasio pendapatan terhadap biaya pemasaran.

\subsection{User Interface}

User Interface (UI), dalam bidang desain industri interaksi manusia-komputer, adalah ruang di mana interaksi antara manusia dan mesin terjadi. Tujuan dari interaksi ini adalah untuk memungkinkan operasi dan kontrol alat berat yang efektif dari ujung manusia, sementara alat berat secara bersamaan mengumpan balik informasi yang membantu proses pengambilan keputusan operator. Contoh konsep antarmuka pengguna yang luas ini mencakup aspek interaktif sistem operasi komputer, perkakas tangan, kontrol operator alat berat, dan kontrol proses. Pertimbangan desain yang berlaku saat membuat antarmuka pengguna terkait atau melibatkan disiplin ilmu seperti ergonomi dan psikologi.

Secara umum, tujuan dari desain antarmuka pengguna adalah untuk menghasilkan antarmuka pengguna yang membuatnya mudah, efisien, dan menyenangkan (user-friendly) untuk mengoperasikan mesin dengan cara yang menghasilkan hasil yang diinginkan. Ini umumnya berarti bahwa operator perlu memberikan input minimal untuk mencapai output yang diinginkan, dan juga bahwa mesin meminimalkan output yang tidak diinginkan kepada manusia.

\subsection{User Experience}

Desain User Experience (UX) adalah proses yang digunakan tim desain untuk menciptakan produk yang memberikan pengalaman yang bermakna dan relevan bagi pengguna. Ini melibatkan desain seluruh proses untuk memperoleh dan mengintegrasikan produk, termasuk aspek branding, desain, kegunaan dan fungsi.

"Desain User experience" sering digunakan secara bergantian dengan istilah-istilah seperti "User experience design" dan "Usability". Namun, sementara desain usability dan antarmuka pengguna (UI) adalah aspek penting dari desain UX, mereka adalah himpunan bagian dari itu - desain UX mencakup beragam bidang lainnya, juga. Seorang perancang UX memusatkan perhatian pada seluruh proses memperoleh dan mengintegrasikan suatu produk, termasuk aspek branding, desain, kegunaan, dan fungsi. Ini adalah kisah yang dimulai sebelum perangkat ada di tangan pengguna.

\subsection{Instrumen Penelitian}

Pada penelitian ini menggunakan instrument penelitian dengan perangkat lunak open-source yaitu Piwik yang kini berubah nama menjadi Matomo. Matomo, sebelumnya Piwik (diucapkan / 'pi:wi:k /), adalah aplikasi analisis web sumber terbuka dan gratis yang dikembangkan oleh tim pengembang internasional, yang beroperasi pada server web PHP / MySQL. Ini melacak kunjungan online ke satu situs web atau lebih dan menampilkan laporan kunjungan ini untuk dianalisis. Pada Juni 2018, Matomo digunakan oleh lebih dari 1.455.000 situs web, atau 1,3\% dari semua situs web dengan alat analisis lalu lintas yang dikenal, dan telah diterjemahkan ke dalam 54 bahasa, Versi baru dirilis secara berkala. 


\subsection{Studi Terkait}

Penelitian Syahrial dkk, yang berjudul Analisa Statistik Pengunjung Situs Resmi Universitas Syiah Kuala (www.unsyiah.ac.id). Menghasilkan laporan statistik situs resmi Unsyiah. Adapun hasil yang disajikan antara lain tren/ karakteristik pengunjung dan segmentasi pengunjung. Pada tren/ karakteristik pengunjung terdiri dari beberapa bagian antara lain jumlah pengunjung, jumlah pengunjung unik, jumlah halaman yang dibuka, rata-rata pageview untuk satu kali kunjungan, lama pengunjung berkujung ke situs, bounce rate. Sementara pada segmentasi data pengunjung terdari dari hasil analitik untuk Bahasa yang digunakan pada browser, lokasi isp yang dipakai pengunjung, jenis browser yang digunakan pengunjung, resolusi layar yang digunakan pengunjung, sistem operasi yang digunakan pengunjung, browser pengunjung yang sudah terpasang plugin flash, browser pengunjung yang sudah terpasang java, jumlah pengunjung tiap negara, Jumlah pengunjung tiap kota. Loyalitas pengunjung merupakan banyaknya pengunjung yang berkunjung kembali ke website tersebut. Sementara untuk sumber dari kunjungan (traffic source) terdiri dari beberapa bagian sumber antara lain keyword (kata kunci), search engine, Referring Sites, Direct traffic, Top Content.

Dalam penelitian yang berjudul “Web Analytic Untuk Pengukuran Dampak Social Media Campaign Blog Socialgadgetnews.Com" oleh Lady JoanneTjahyana dkk, memuat langkah dalam pelaksanaan dan pengukuran social media campaign berdasarkan Objectives And Key Results (OKR) dan Key Performance Indicators (KPI), dengan langkah - langkah antara lain membuat akun social media, Social media campaign untuk mempromosikan setiap blog post, berkampanye melalui iklan di social media, mengadakan giveaway, mengadakan survey.

Dengan hasil dalam pelaksanaan social media campaign untuk mempromosikan blog SocialGadgetNews.com ini, telah dapat disimpulkan bahwa faktor yang dapat menarik pengunjung untuk datang pada blog tersebut adalah topik blog post yang menarik, serta pembuatan akun social media untuk blog SocialGadgetNews.com tersebut. Hal ini dibuktikan dengan banyaknya unique pageviews yang didapat dari kedua faktor di atas yang telah mendatangkan 10 unique pageviews terbanyak.

Dalam penelitian berikutnya yang berjudul "Analisis Web Menggunakan Google Analytic Untuk Menyajikan Laporan Data Situs Dalam Proses Optimasi” oleh Ade Andri Hendriadi dkk, yang dalam penelitiannya menggunakan Google Analytics yang terdiri dari 4 komponen yang menggambarkan bagaimana cara google analytics tersebut bekerja seperti gambar berikut ini :

Gambar 1. Proses Google Analytic
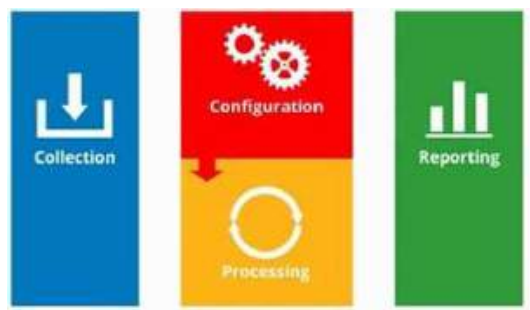

Collection, Tahap ini berbicara tentang bagaimana memperoleh data kedalam google analytics. Untuk memperoleh data, harus ditambahkan google analytics code kedalam website, aplikasi mobile ataupun berbagai peralatan digital lainnya yang ingin diukur. Kode ini akan merekam semua aktifitas user didalam website anda. Kode ini ada beberapa jenis dan tergantung untuk mengukur apa, sebagai contoh untuk website kode ini berupa javascript yang diletakkan diantara tag $<$ head $></$ head $>$, sedangkan untuk aplikasi mobile dalam bentuk SDK (Software Development Kit).

Configuration \& Processing, Selama permrosesan data, google analytics merubah data mentah dari proses collection tadi menggunakan pengaturan dalam google analytics account. Pengaturan ini disebut configuration, contohnya ketika menyaring data dengan menggunakan menu filter di google analytics lalu data akan di proses.

Reporting, setelah google analytics menyelesaikan langkah processing, dapat diakses dan menganalisa data anda menggunakan reporting interface yang mudah digunakan dan visualisasi data. Google analytics juga menyediakan Google Analytics Core Reporting API untuk mengkustomisasi report, tentunya dengan bantuan programmer atau pihak ketiga yang mengerti penggunaan API. 


\section{HASIL DAN PEMBAHASAN}

\subsection{Implementasi Instrumen Penelitian}

Penelitian ini akan mengambil data pengunjung dari website portal resmi yaitu www.upnvi.ac.id dengan mesin web analytics (Matomo) berada pada server yang berbeda dengan alamat https://piwik.upnvj.ac.id. Adapun gambaran arsitektur web analytics sebagai berikut :

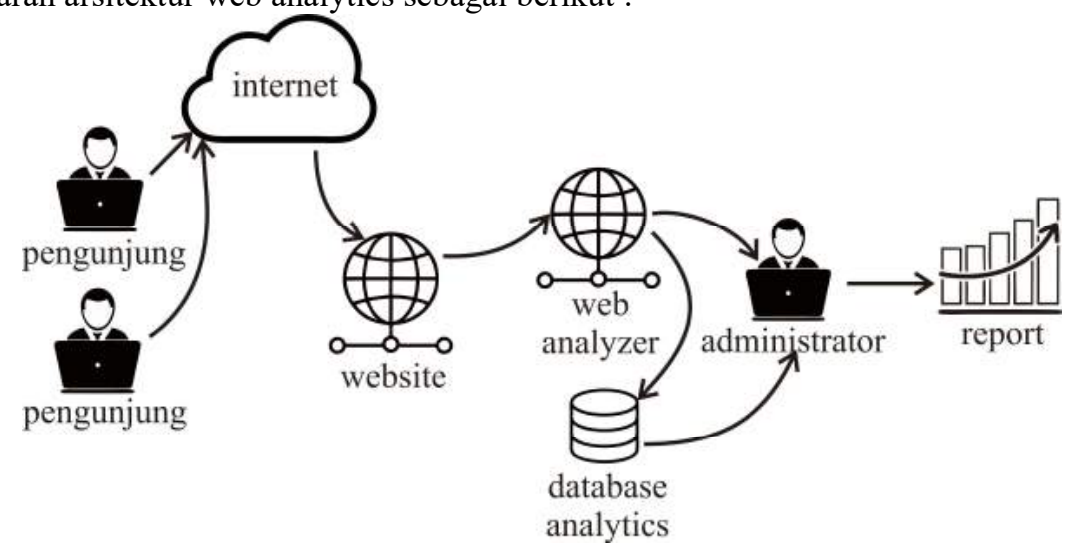

Gambar 2. Arsitektur Web Analytics

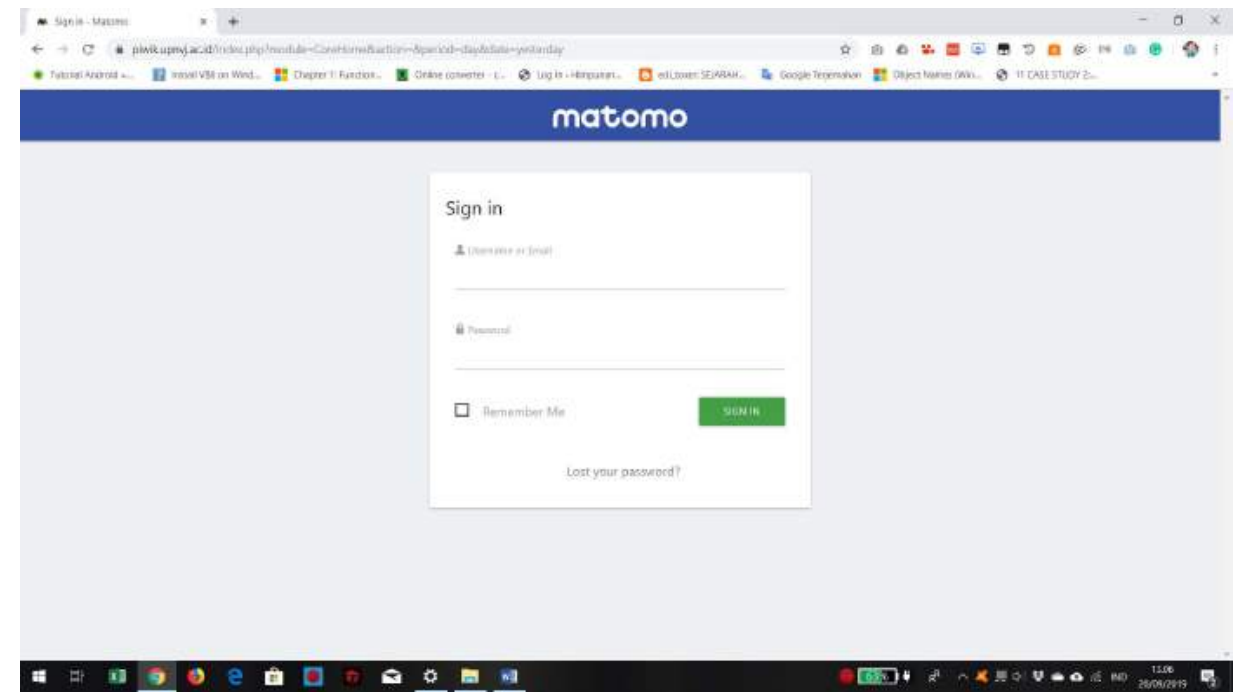

Gambar 3. Halaman Login Matomo 


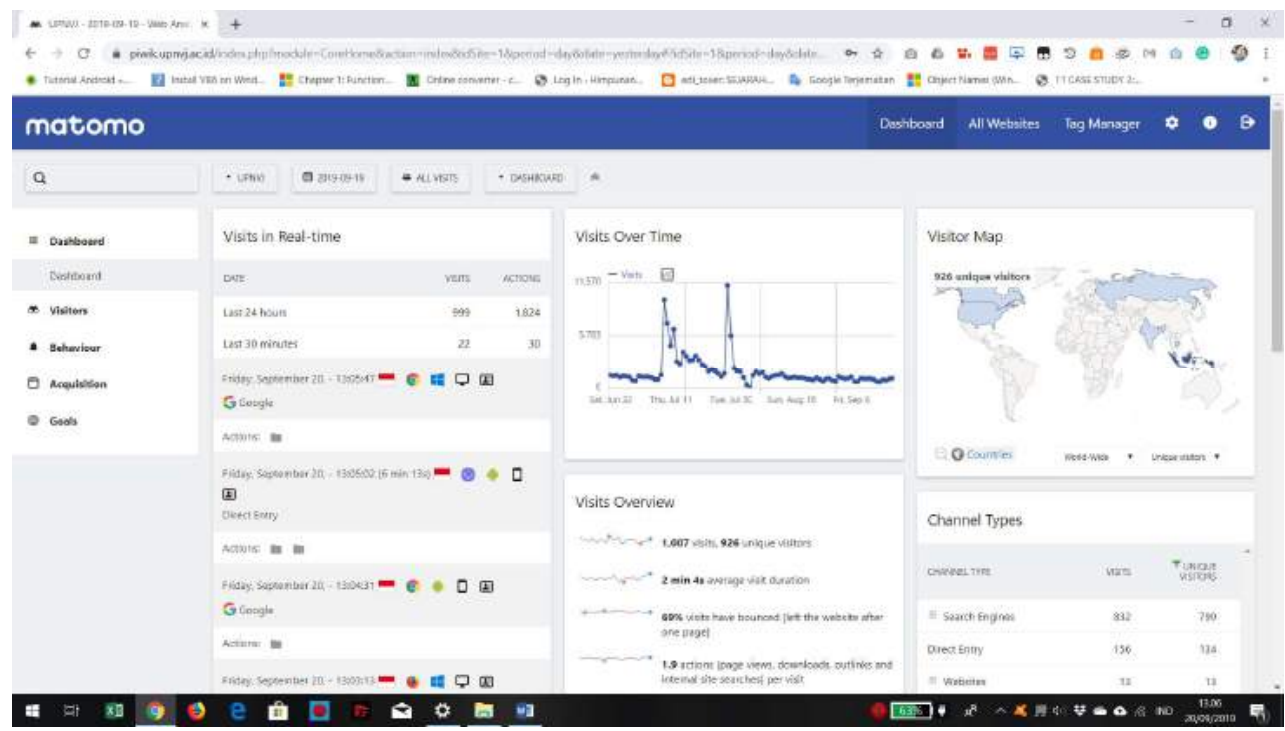

Gambar 4. Tampilan Dashboard Matomo

Terdapat banyak elemen data yang dapat diakusisi oleh aplikasi tersebut dengan variable sebagai berikut :

Tabel 1. Data Variable Analytics

\begin{tabular}{llll}
\hline Komponen & & & \\
\hline Visitors & Behavior & Acquisition & Goals \\
\hline Overview & Pages & Overview & Overview \\
\hline Visit Log & Entry pages & All Channels & Add a new Goal \\
\hline Real-time & Exit pages & Search Engines \& Keyword & \\
\hline Real-time Map & Page titles & Websites & \\
\hline Locations & Site Search & Social Networks & \\
\hline Devices & Outlinks & Campaigns & \\
\hline Software & Downloads & Campaign URL Builder & \\
\hline Times & Events & & \\
\hline User IDs & Contents & & \\
\hline Customs Variable & Engagement & & \\
\hline & Transitions & & \\
\hline
\end{tabular}

\subsection{Hasil Monitoring dan Analisa}

Data hasil monitoring dapat diambil dalam bentuk spreadsheet maupun dalam bentuk grafik gambar. Pada penelitian ini ditampilkan data yang sudah dalam bentuk gambar. Untuk menyajikan data instrumen dapat diatur kurun waktu yang akan diambil, disesuaikan dengan rentang waktu yang akan diolah datanya. Data diambil mulai dari 25 Maret 2019 sampai dengan 12 November 2019.

Tabel 2. Visit Overview

\begin{tabular}{lll}
\hline No. & Variable & Jumlah \\
\hline 1 & visits & 301.471 \\
\hline 2 & pageviews & 480.296 \\
\hline 3 & unique pageviews & 390,591 \\
\hline 4 & average visit duration & $1 \mathrm{~min} 36 \mathrm{~s}$ \\
\hline 5 & total searches on website & 7.094 \\
\hline 6 & unique keywords & 2.598 \\
\hline 7 & visits have bounced & $65 \%$ \\
\hline 8 & outlinks & 70.806 \\
\hline 10 & unique outlinks & 62.348 \\
\hline 11 & average generation time & $0.83 \mathrm{~s}$ \\
\hline
\end{tabular}


Tabel 3. 10 Negara Visitor

\begin{tabular}{lll}
\hline No. & Negara & Jumlah \\
\hline 1 & Indonesia & 294.025 \\
\hline 2 & United States & 2.769 \\
\hline 3 & Unknown & 1.289 \\
\hline 4 & Singapore & 933 \\
\hline 5 & Malaysia & 258 \\
\hline 6 & South Africa & 252 \\
\hline 7 & Netherlands & 214 \\
\hline 8 & United Kingdom & 208 \\
\hline 9 & Germany & 206 \\
\hline 10 & Japan & 149 \\
\hline
\end{tabular}

Tabel 4. 5 Jenis Perangkat Pengunjung

\begin{tabular}{lll}
\hline No. & Tipe & Jumlah \\
\hline 1 & Smartphone & 198.417 \\
\hline 2 & Desktop & 74.991 \\
\hline 3 & Phablet & 24.849 \\
\hline 4 & Tablet & 1.982 \\
\hline 5 & Unknown & 1.221 \\
\hline
\end{tabular}

Tabel 5. 10 Konfigurasi Umum Pengunjung

\begin{tabular}{lll}
\hline No. & Ragam Konfigurasi & Jumlah \\
\hline 1 & Android / Chrome Mobile / 360x640 & 76.885 \\
\hline 2 & Windows / Chrome / 1366x768 & 32.479 \\
\hline 3 & iOS / Mobile Safari / 375x667 & 18.659 \\
\hline 4 & Android / Chrome Mobile / 360x760 & 17.819 \\
\hline 5 & Android / Chrome Mobile / 360x720 & 15.290 \\
\hline 6 & Windows / Firefox / 1366x768 & 7.968 \\
\hline 7 & iOS / Mobile Safari / 414x736 & 7.881 \\
\hline 8 & Android / Chrome Mobile / 412x846 & 6.797 \\
\hline 9 & Android / Samsung Browser / 360x640 & 6.343 \\
\hline 10 & Android / Chrome Mobile / 360x780 & 149 \\
\hline
\end{tabular}

Tabel 6. Waktu Jam Pengunjung

\begin{tabular}{llllllll}
\hline Jam & Jumlah & Jam & Jumlah & Jam & Jumlah & Jam & Jumlah \\
\hline 00 & 6.680 & 06 & 7.048 & 12 & 15.253 & 18 & 16.637 \\
\hline 01 & 3.714 & 07 & 9.964 & 13 & 16.990 & 19 & 17.831 \\
\hline 02 & 2.331 & 08 & 13.934 & 14 & 16.621 & 20 & 19.000 \\
\hline 02 & 1.989 & 09 & 16.072 & 15 & 16.653 & 21 & 19.020 \\
\hline 04 & 2.835 & 10 & 18.109 & 16 & 16.203 & 22 & 14.722 \\
\hline 05 & 5.073 & 11 & 17.800 & 17 & 16.460 & 23 & 10.532 \\
\hline
\end{tabular}

Tabel 7. 10 Halaman Terbanyak Dibuka

\begin{tabular}{lll}
\hline No. & Halaman Website & Jumlah \\
\hline 1 & UPN Veteran Jakarta & Kampus Bela Negara (index) \\
\hline 2 & Daftar Program Studi & 160,152 \\
\hline 3 & Klasifikasi Arsip : File Akreditasi & 92,482 \\
\hline 4 & Kalender Akademik & 17,502 \\
\hline 5 & Biaya Pendidikan & 11,228 \\
\hline 6 & Detail - Arsip & 8,799 \\
\hline 7 & Lokasi Kampus & 6,141 \\
\hline 8 & Pengumuman Hasil SBMPTN 2019 & 6,011 \\
\hline 9 & Sejarah & 4,956 \\
\hline 10 & Pimpinan Universitas & 4,798 \\
\hline
\end{tabular}


Tabel 8. 10 Kata Kunci Pencarian

\begin{tabular}{lll}
\hline No. & Kata Kunci & Jumlah \\
\hline 1 & akreditasi & 93 \\
\hline 2 & Akreditasi & 77 \\
\hline 3 & Biaya & 37 \\
\hline 4 & Ukt & 36 \\
\hline 5 & Farmasi & 33 \\
\hline 6 & biaya & 32 \\
\hline 7 & ukt & 31 \\
\hline 8 & pkm & 30 \\
\hline 9 & wisuda & 30 \\
\hline 10 & Beasiswa & 29 \\
\hline & &
\end{tabular}

Tabel 9. Outlink Click

\begin{tabular}{lll}
\hline No. & Pranala & Jumlah \\
\hline 1 & penmaru.upnvj.ac.id & 29,541 \\
\hline 2 & fisip.upnvj.ac.id & 6,007 \\
\hline 3 & fikes.upnvj.ac.id & 5,513 \\
\hline 4 & fik.upnvj.ac.id & 4,637 \\
\hline 5 & feb.upnvj.ac.id & 4,237 \\
\hline 6 & fk.upnvj.ac.id & 3,701 \\
\hline 7 & ft.upnvj.ac.id & 3,449 \\
\hline 8 & www.upnvj.ac.id & 2,874 \\
\hline 9 & fh.upnvj.ac.id & 1,797 \\
\hline 10 & ppid.upnvj.ac.id & 1,106 \\
\hline
\end{tabular}

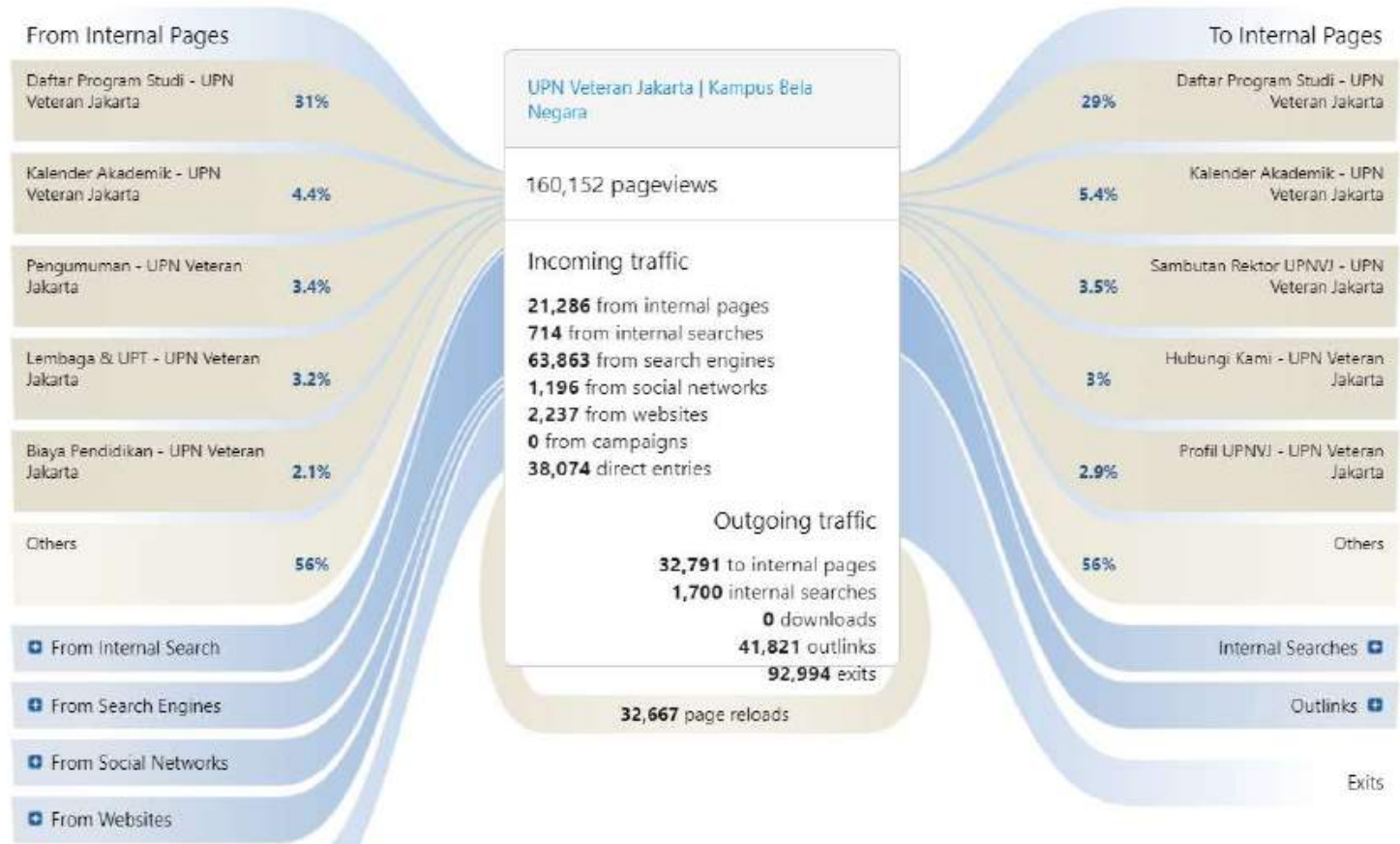

Gambar 5. Transisi antar halaman dalam website

\section{KESIMPULAN}

Melihat data - data yang disajikan di atas, bahwa instrument tersebut dapat menarik dan menyajikan data analitik sesuai dengan kebutuhan pengembangan berikutnya. Berdasarkan Tabel 4. Jenis perangkat pengunjung maka pengembangan UI lebih diarahkan ke desain yang responsive dengan smartphone dilengkapi dengan data pada tabel 5. Konfigurasi umum pada perangkat pengunjung maka desain UI website 
lebih diarahkan pada perangkat smartphone dengan operating system Android, dengan browser Chrome Mobile, serta resolusi layer yang cukup kecil yaitu 360x640 piksel.

Memperhatikan Tabel 6 jam pengunjung membuka website dapat dilihat bahwa peak pengunjung antara jam 08 sampai jam 21, ini dapat menjadi masukkan untuk bagian infrastruktur server dalam menghadapi kunjungan website terbanyak pada waktu tersebut. Sebagai contoh untuk penerapan dynamic balancing website.

Memperhatikan Tabel 7 dan Tabel 8, hasil informasinya lebih diarahkan ke pengembahan UX dimana komponen tersebut lebih kearah pemenuhan informasi yang disediakan website. Pemutakhiran data pada halaman website serta hasil pencarian dengan kata kunci tertentu yang dimasukkan oleh pengunjung menjadi tolak ukur kepuasan pengunjung dalam pemenuhan informasi.

Memperhatikan Tabel 9 outlink, dimana pranal tersebut merupakan tujuan berikutnya setelah pengunjung merasa selesai atau kurang puas di website utama, maka penungjung akan membuat website lain yang masih tercantum pranalanya dalam website utama. Sehingga website - website lain tersebut perlu dimutakhirkan data dan informasinya.

\section{Referensi}

[1.] Hendriadi, A. A. (2015). Analisis Web Menggunakan Google Analytic utuk Menyajikan Laporan Data Situs dalam Proses Optimasi. Jurnal Ilmiah Solusi, 1(4), 7-19.

[2.] Joannetjahyana, Lady, Marsefio, \&, \& Luhukay, S. (2014). Web Analytic Untuk Pengukuran Dampak Social Media Campaign Blog Socialgadgetnews.Com. Jurnal Scriptura, 4(1).

[3.] Munadi, K., \& Kunci, K. (2010). Analisa Statistik Pengunjung Situs Resmi Universitas Syiah Kuala (www.unsyiah.ac.id). Jurnal Rekayasa Elektrika, 9(2), 49-54.

[4.] Wiryawan, M. B. (2011). User Experience (Ux) sebagai Bagian dari Pemikiran Desain dalam Pendidikan Tinggi Desain Komunikasi Visual. Humaniora, 2(2), 1158.

[5.] https://searchbusinessanalytics.techtarget.com/definition/Web-analytics (03/12/2019 17:00)

[6.] https://www.interaction-design.org/literature/topics/ux-design (03/12/2019 17:00) 